\title{
RTN4 wt Allele
}

National Cancer Institute

\section{Source}

National Cancer Institute. RTN4 wt Allele. NCI Thesaurus. Code C52103.

Human RTN4 wild-type allele is located within 2p14-p13 and is approximately 79 kb in length. This allele, which encodes reticulon 4 protein, plays a role in neurite outgrowth inhibition. 